ROCZNIKI PEDAGOGICZNE

Tom 13(49), numer $1-2021$

DOI: https://doi.org/10.18290/rped21131.3

REV. MAREK JEZIORAŃSKI

\title{
EDUCATIONAL RELATIONSHIP IN THE CONTEXT \\ OF KAROL WOJTYŁA'S MORAL TEACHING ABOUT THE HUMAN ACT
}

\begin{abstract}
INTRODUCTION
The presented formulation of the subject of this article indicates the following main problem: How should the educational relationship be presented when it is done from the perspective of the moral teaching about the human act by Karol Wojtyła (1920-2005)? On the one hand, we have the phenomenon of the educational relationship, which can be presented as the material subject of the issues under consideration. On the other hand, this subject is described and then assessed from the perspective of the moral doctrine about the human act of K. Wojtyła. However, I would like to point out straight away that from the full extent of the human act of K. Wojtyła, I choose the issue of the 'moment of causation.' I take up the justification for this choice in the section entitled Explanation of categories related to the formal subject. This research approach is described as a formal research subject.

In order to answer the main question of the article, the sequence of actions should be presented. First, the understanding of the material subject will be presented. Its scope includes such categories as: upbringing; relationship and educational relationship. Secondly, the scientific perspective of the analyzed reality will be presented, i.e.: the moral teaching about the human act by K. Wojtyła. The last stage of the research will be to present the conditions of a good (proper) educational relationship seen from the perspective of the moral teaching about the human act by K. Wojtyła. The aim of the ar-
\end{abstract}

Rev. dr MAReK JeZIORAŃSKi - Department of General Pedagogy, Institute of Pedagogy, The John Paul II Catholic University of Lublin; address for correspondence: Al. Racławickie 14, 20-950 Lublin; e-mail: marekj@kul.pl; ORCID: https://orcid.org/0000-0002-9770-835X. 
ticle formulated in this way may raise doubts due to the statements used in it assessing what goes beyond science in the strict (positivist) sense. Nevertheless, we can use such statements here, because we are entitled and even obligated to do so by the fact that we describe the educational relationship in the context of moral teaching, i.e. ethics, which is a normative science. Deduction will be the main research method and the rationale for logical reasoning is: 1) understanding of upbringing and 2) teaching about the 'moment of causation' of K. Wojtyła.

\section{EXPLANATION OF CATEGORIES RELATED TO THE MATERIAL SUBJECT}

The basic categories undertaken in this article are: upbringing, relationship and educational relationship. In this order, they will be presented to clarify the content.

Upbringing is an ambiguous term, mainly due to the ontological conditions, which are differently accepted in different concepts and pedagogical schools. Thus, a very serious problem arises from the very beginning of this main area of research. It seems that this problem can be solved in two ways: either to clearly opt for the chosen pedagogical school (with its axioms) or to seek a neutral, universal and general understanding of education. I believe that the formal perspective adopted in this article can be applied to many / all (?) ways of defining upbringing, so I will go the latter way.

Stefan Kunowski, among others, undertook work related to the search for some kind of pandefinition of upbringing. By doing so, he wanted to give a fully universal description of the basic pedagogical phenomenon, which is upbringing, so that there would be a specific common platform for pedagogical research. His research ultimately led him to the distinction between the four boundaries within which upbringing is carried out. As he writes himself: "The framework for the phenomenon of upbringing is, on the one hand, (1) the older generation of society and (2) its system of directing actions towards youth, on the other hand, (3) the ideal of the new man and (4) the future shape of life as goals to be achieved" (Kunowski, 2004, p. 170). Then, on the basis of these distinctions, he gives his definition of upbringing: "Upbringing is always a socially recognized system of action of the older generations on adolescents in order to guide their comprehensive development to prepare a new man for the future life according to a specific ideal" (ibidem, 
p. 170), which, unfortunately, apart from mentioning the above limits in one sentence, does not add nor bring new content. On the basis of the above it can be concluded that Kunowski did not work out a definition of upbringing but only defined the limits of the researched phenomenon. This is not an accusation, of course, but only a statement that the goal he set for himself was not fully achieved, although his contribution to the search for the widest possible definition of upbringing is invaluable.

The question remains, however, as to whether such a definition satisfies all researchers in this subject. It seems that not only does this definition not do so, but no other has little chance of assuming the role of a kind of pandefinition of upbringing. This belief is based primarily on historical verification. This is the position of the German educator Friedrich W. Kron, for example, who wrote: "It is not a good idea to try to formulate an omni-definition, although such attempts are still being made" (Kron, 2012, p. 46). Interestingly, however, he did not mind that in the next edition of his book the issue of upbringing should begin with a short definition formula, which he presented as follows: "Upbringing is the conscious and/or planned influence of people, especially adults" (Kron, Jürgens, Standop, 2013, p. 44).

Similarly, Krzysztof Rubacha, when addressing the issues of basic pedagogical concepts, points to their differentiation and hierarchy in terms of the degree of generality. He considers the concept of education as the most general $^{1}$, which he defines after Bogusław Milerski and Bogusław Śliwerski as follows: "Education is the totality of interactions that serve to form (change, develop) human life skills" (Rubacha, 2005, p. 25). Then, each of these three essential elements (interaction, formation, life skills) is specified, while at the same time externalizing the ontological, anthropological, axiological, teleological, etc. assumptions made. At this initial level, however, at least in a declarative way, they take into account the axiomatic neutrality.

The conclusion of the above analyses is as follows. In my research, I am based on the general understanding of upbringing, realizing that this description does not function as an omni-definition and requires an axiomatic definition for various applications.

Another category of the article is the relationship. As a scientific term it has a centuries-long tradition. It was introduced to the scientific language already by Aristotle (Ostrowska, 2006, p. 183). The Greek pros ti was rendered by the Latin relatio, which comes from referre - to refer. The relationship, therefore, is "the assignment of anything to anything" (Krąpiec, 2007, p. 712).

\footnotetext{
${ }^{1}$ In this article, I understand terms such as "upbringing" and "education" synonymously.
} 
It is a very general and basic definition of a relationship on the basis of which the research specificity of individual sciences (e.g. sociology or psychology) specifies its meaning in relation to its research. At this point I am not going to show and list these examples. Staying with a very general - philosophical approach, it can be specified that "relationship" is "a reference, the consequence of which is a way of being between two boundariess" (ibidem).

The last category (educational relationship) is a combination of the two above and belongs to the specificity of the issues addressed in the article. If upbringing is called "the influence of people [on each other]" (F.W. Kron) or "the totality of the interactions that serve to form (change, develop) human life skills." (K. Rubacha) and the relationship: The "assignment of anything to anything" for a specific purpose, this educational relationship will be the assignment of two persons to each other, the purpose of which is to influence the formation of the human life skills. This definition of the educational relationship results from the deductive way in which research is conducted at this stage. In other words, the educational relationship will be a relationship between two people (who are called the 'educator' and the 'pupil'), the aim of which is to develop the life skills of at least one of them.

As a complement, we can recall another pioneering study by Herman Nohl (1879-1960), who was the first to introduce the term "educational relationship" into the language of pedagogy (der pädagogische Bezug) (Gaus, 2012, p. 483). He defined it as follows: "The basis of education is the emotional/ desirable/emotional relationship (leidenschaftliches Verhältnis) of a mature man to a growing man (zum werdenden Menschen), and this for his or her own sake, so that they may reach their life and their form" (Nohl, 1988, p. 169).

A detailed description of the "educational relationship" requires the definition of (1) the correlates of the relationship (educator and pupil), (2) the specificity of the relationship, and (3) the purpose for which the relationship is formed. Research can also be undertaken in the area of (4) the sociocultural environment within which the educational relationship takes place. However, these are issues that go beyond a strict understanding of the issue addressed in this article. 


\section{EXPLANATION OF CATEGORIES \\ RELATED TO THE FORMAL SUBJECT}

The next step is to clarify the importance of the research aspect. It was said that it is the moral teaching about the human act of K. Wojtyła. Therefore, it is necessary to present here such categories as: moral teaching and human act according to K. Wojtyła. Explanation of this issue in further analyses will serve as the adoption of a specific way of looking, describing and evaluating the educational relation.

Moral science (or more precisely, science about morality) is - in other words - ethics. It is defined as: "the theory of the act (that is, its material subject) in terms of moral duty (that is, its formal subject)" (Szostek, 2008, p. 33). In the light of this definition, it is necessary to clarify the understanding of both the human act and the moral duty by K. Wojtyła in order to understand how the moral teaching about the human act affects the understanding of the educational relationship.

For K. Wojtyła, the act is connected exclusively with the action of man. Only man fulfils a certain act and fulfils himself/herself in the act. However, not everything that happens through and in man can be called a human act. A human act in the strict sense, and such an understanding here is crucial, will be "only an action of which man is the conscious and free originator" (ibidem, p. 35). Hence, an important element recognizable as a human act from other human acts is the "moment of causality'! It is the decisive one: the experience of experiencing "I am the originator" (Wojtyła, 2011, p. 116). Such an experience is impossible without two conditions: freedom and awareness. Such a form of human activity K. Wojtyła (after classical philosophy) calls: actus humanus - human act.

In man, there are also other forms of activity, which cannot be called human acts. He distinguishes the following:

1."Something is happening to me." - The human being passively experiences various kinds of sensations within himself/herself; it is mainly about sensations from outside. Man here experiences himself/herself as an object affected by other object or other force (ibidem, p. 112).

2. "Something is happening inside me." - The human being passively experiences different kinds of sensations within himself/herself; it is primarily about sensations from the inside. It is, for example, about experiencing processes: biological, mental, physical. This form is a different kind of actus hominis - an act of human being. 
These two forms of activity are therefore not human acts (actus humanus) because they lack the 'moment of causation.' To sum up, only an act in which a person experiences themselves as their free and conscious originator can be called a human act. Freedom and awareness of action are constitutional features of the human act. On the basis of the above, I consider the issue of the 'moment of causation' to be crucial in the area of the formal subject matter of the issue.

Another issue is the explanation of what the moral duty according to K. Wojtyła is based on. It is, therefore, a search for a criterion for the evaluation of the human act. In other words, it is necessary to answer the question of what moral system K. Wojtyła adopted to evaluate the human act from his perspective.

Generally speaking, K. Wojtyła assesses the human act from the position of personalistic ethics (cf. ibidem, p. 157), which, in synthetic terms, "expresses the conviction that an act - which not only comes from the human person, but also has as its 'addressee' a person (sometimes the subject's own person) - is morally good in that it constitutes an act of affirmation of the person for themselves: that it is primarily concerned with the good of the person of the 'addressee' (if such a metaphor can be used) (Szostek, 2008, p. 65). The fundamental aspect of evaluating conscious and free human action will therefore be the question of "affirming the person for himself/ herself." This means that everything that will conform to this norm will be judged appropriate (positive) and those actions that do not conform to this criterion will be judged negative.

\section{THE CONDITIONS OF A GOOD EDUCATIONAL RELATIONSHIP FROM THE PERSPECTIVE OF THE MORAL TEACHING ABOUT THE HUMAN ACT BY K. WOJTYŁA}

The last stage of the research consists in combining issues concerning the educational relation with the conditions of moral teaching of K. Wojtyła. Two problem areas can be identified. First of all, the understanding of the human act should be 'imposed' on the predefined educational relation, which will give the understanding of the educational relation as a human act. Secondly, the moral teaching of K. Wojtyła applied to the evaluation of the human act will become a criterion for the evaluation of the educational relationship and will enable to distinguish its good qualities. 
If the human act is only such an act which is characterized by the 'moment of causation,' that is, a free and conscious action of man, then upbringing as a human act can be spoken of only when it is undertaken in a free and conscious manner. When speaking of the educational relationship, attention should be paid above all to its correlates, i.e., the educator and the pupil (because the conditions are applied to them) and from among their various mutual references, only those in which the 'moment of causality' is inscribed should be distinguished. Bearing in mind that it involves the condition of free and conscious action, it must be said that until these conditions are met, there can be no educational relationship understood as a human act. Hence:

1. it will be possible to talk about educational relationship only if, on at least one side (e.g. from the educator's side), the activity will be carried out in a free and conscious manner. It will be a one-sided relationship in which the charge experiences education as an external action directed at him/her;

2. in a situation where free and conscious action is taken on both sides, we can speak of a bilateral educational relationship;

3. we cannot talk about an educational relationship if even one of the above conditions is missing. Consciousness is related to cognition. Hence, in order for the educator (or the educated person) to be able to undertake the educational activity, he/she must get to know what this activity is about. What is the essence of education. On the other hand, freedom of action is associated with the possibility of choice and decision. We can speak of "freedom from" and "freedom to." The former indicates the state of a man who controls himself, states about himself. On the other hand, "freedom to" indicates a real possibility to choose between many proposals. Thus, there will be no educational relationship where a man, for various reasons, does not have control over himself, or - to put it in the language of K. Wojtyła - he does not control himself. These will be situations of internal restrictions (dependence on addictions, vices, etc.) and external (restriction of freedom, acting under the influence of other people, acting under the pressure of people, systems or ideology). Both awareness and freedom are gradual, so the updating of the educational relationship will be gradual too.

The last stage is assigning the criterion of moral evaluation to the educational relationship understood as a human act. It has been proved above that it is a personalistic criterion, which can be expressed in the words: "the act of affirming a person for himself/herself." In specifying this general norm to the area of pedagogy, one can use the understanding of upbringing mentioned earlier by K. Rubacha, which aims at accomplishing development po- 
tential, understood very broadly. Hence the conclusion that educational activities in this theoretical perspective are ultimately always to serve the charge and not other entities or circumstances, such as the social welfare, maintaining certain social, cultural, religious structures, etc. In this respect, this criterion can be operationalized in relation to the elements of the educational process:

1. With regard to the purpose of education: the educator towards the pupil (and then the pupil towards himself/herself) is obliged to recognize and update the authentic personal good. I realize that it is very difficult to define the term "authentic personal good" and that it is not possible without taking into account the anthropological and philosophical assumptions, nevertheless - without going into detailed solutions - at this point it is necessary to emphasize the intentional honesty of the educator towards the pupil. In this context, Andrzej Szostek also interprets activities related to assistance in self-upbringing. He asks rhetorically: "Does a good educator not try to help the pupil himself/herself, so that they can see the good that they should follow in life?" (Szostek, 2008, p. 67). Situations of exerting influence on the charge, which do not serve their genuine good, but they are rather supposed to serve other goals, created either by the educator or by the social environment should be assessed negatively.

2. With regard to educational measures: "affirmation of a person for himself/herself" secures not only the intentionality of educational activities, but also regulates the selection of educational measures. In this respect, we can talk about right and wrong measures, methods and techniques of upbringing. The right ones are those that correspond to a specific pupil, taking into account his/her developmental (biological, intellectual, social, emotional, religious...) conditions and lead to the implementation of the intended goal of upbringing, which - generally speaking - is always the accomplishment of the pupil's development potential (in other words: his / her developmental good). Therefore, it is unlawful to use the developed methods, means, techniques, etc. of education indiscriminately, without taking into account the individuality of the pupil. It is also incorrect to use such a methodology which, although brings tangible benefits in terms of the current situation of the charge, but it prevents or hinders the achievement of the full development of the personal good. 


\section{CONCLUSIONS}

The above mentioned argument presents the search related to the understanding of the educational relation in the perspective of specific ethical assumptions. Attempts to undertake such activities are justified at least because of the fact that pedagogy as a descriptive-normative science and its various directions are always based on previous assumptions, which also include those concerning specific ethical systems. However, this is not always expressed explicitly.

In this case, the research undertaken has been related to the understanding of the educational relation in the light of the moral teaching about the human act of K. Wojtyła. The undertaken analyses led to the following conclusions:

1. The authentic educational activity is only one that is freely and consciously fulfilled by man; the so-called 'moment of causality' is emphasized here.

2. Good, from the position of the accepted ethical system, is an educational activity which corresponds to the personalistic norm. This means, however, that:

3. Upbringing is to serve the achievement of the authentic personal good of the pupil;

4. The educational measures used must be just, i.e., they must correspond to the individual circumstances of the pupil and lead to the fulfilment of the goal set.

I am aware that the analyses undertaken remain at a very general level. On the basis of the above mentioned conclusions it would be necessary to consider their operationalisation. However, such an action - although very useful from a pragmatic point of view - goes beyond the strict framework of the deduction method I have adopted for my research. Therefore, the contents of the article presented in this way invite to discussion and further analysis.

\section{BIBLIOGRAPHY}

Gaus, G.D. (2012). Pädagogischer Bezug. In: Klinkhardt Lexikon Erziehungswissenschaft. K-P. Horn, H. Kemnitz, W. Marotzki, U. SAndfuchs (Eds.), vol. 2 (p. 483). Bad Heilbrunn: Verlag Julius Klinkhardt.

KrąPIEC, M.A. (2007). Relacja. In: Powszechna encyklopedia filozofii, A. MARYNIARCZYK et all. (Eds.), vol. 8 (p. 712-716). Lublin: Polskie Towarzystwo Tomasza z Akwinu.

Kron, F.W., JÜrgens, E., StAndop, J. (2013). Grudwissen Pädagogik. München: Ernst Reinhardt Verlag. 
Kron, F.W. (2012). Pedagogika. Kluczowe zagadnienia. Sopot: GWP.

KunOwski, S. (2004). Podstawy wspótczesnej pedagogiki. Warszawa: Wydawnictwo Salezjańskie.

NoHL, H. (1988). Die pädagogische Bewegung in Deutschland und ihre Theorie. Frankfurt/M: Vittoria Klostermann.

OstrowsKa, U. (2006). Relacje interpersonalne w edukacji. In: Encyklopedia pedagogiczna XXI wieku, T. PILCH (Ed.), vol. 5 (p. 179-191). Warszawa: Wydawnictwo Akademickie „Żak.”

Rubacha, K. (2005). Edukacja jako przedmiot pedagogiki i jej subdyscyplin, Pedagogika. Podręcznik akademicki, vol. 1 (p. 21-33). Warszawa: Wydawnictwo Naukowe PWN.

Szostek, A. (2008). Pogadanki z etyki. Częstochowa: Tygodnik Katolicki „Niedziela”.

WoJTYŁA, K. (2011). Osoba i czyn. Lublin: Towarzystwo Naukowe KUL.

\section{EDUCATIONAL RELATIONSHIP IN THE CONTEXT OF KAROL WOJTYŁA'S MORAL TEACHING ABOUT THE HUMAN ACT}

\section{SUMMARY}

The article deals with the issue of understanding the educational relationship from the perspective of K. Wojtyła's moral teaching about human act. It consists of three parts. The first one presents the understanding of the educational relationship, which is the material subject of the main article. The second part operationalizes the issue of moral teaching about the human act as understood by K. Wojtyla, which is the formal subject. The last part presents the conditions of the educational relationship presented in a new theoretical context. The main conclusions include the fact that the essential condition for so interpreted relationship between the educator and the pupil must be the existence of the so-called 'moment of causation,' i.e. the educator's free and conscious involvement in the process of upbringing.

Keywords: upbringing; educational relationship; human act; moral evaluation.

\section{RELACJA WYCHOWAWCZA W ŚWIETLE NAUCZANIA MORALNEGO KAROLA WOJTYŁY O AKCIE CZLOWIEKA}

\section{STRESZCZENIE}

Artykuł podejmuje problematykę rozumienia relacji wychowawczej z perspektywy moralnej nauki K. Wojtyły o akcie człowieka. Składa się z trzech części. W pierwszej przedstawiono interpretację relacji wychowawczej, stanowiącą przedmiot materialny artykułu. Druga część operacjonalizuje problematykę nauczania moralnego o akcie człowieka w rozumieniu Wojtyły, stanowiącą przedmiot formalny artykułu. Ostatnia część przedstawia warunki relacji wychowawczej przedstawionej w nowym kontekście teoretycznym. Wśród najważniejszych wniosków znalazł się fakt, że podstawowym warunkiem tak interpretowanej relacji między wychowawcą a uczniem musi być istnienie tzw. momentu przyczynowego, czyli wolnego i świadomego zaangażowania wychowawcy w proces wychowania.

Słowa kluczowe: wychowanie; relacja wychowawcza; akt człowieka; ocena moralna. 